\title{
Granulomatosis with polyangiitis complicated with bronchopleural fistula
}

\author{
Leyda M Díaz-Correa, ${ }^{1}$ Nicolle de León-Tellado, ${ }^{2}$ Grissel Ríos, ${ }^{1}$ Luis M Viláa
}

${ }^{1}$ Department of Medicine, Division of Rheumatology, University of Puerto Rico Medical Sciences Campus, San Juan, Puerto Rico ${ }^{2}$ Department of Radiology, University of Puerto Rico Medical Sciences Campus, San Juan, Puerto Rico

\section{Correspondence to} Dr Luis M Vilá,

luis.vila2@upr.edu

Accepted 8 September 2014

CrossMark

To cite: Díaz-Correa $\mathrm{LM}_{\text {, }}$ de León-Tellado N, Ríos $\mathrm{G}$, et al. BMJ Case Rep Published online: [please include Day Month Year] doi:10.1136/bcr-2014205145

\section{DESCRIPTION}

Granulomatosis with polyangiitis (GPA) usually involves the upper and/or lower respiratory tracts. Pulmonary manifestations include nodules, pleuritis, fixed infiltrates and alveolar haemorrhage. ${ }^{1}$ Bronchopleural fistulas have been reported in GPA but these are very rare. $^{2}{ }^{3}$ We present a 58 -year-old woman who had a 1-year history of constitutional symptoms, chronic sinusitis, decreased hearing, cough and dyspnoea. On examination, she had a saddle nose deformity, and a bilateral periorbital swelling, chemosis, dacryocystitis and scleritis (figure 1). Bilateral middle ear effusion was observed. Prolonged expiration and wheezing were noticed. Laboratory workup was unremarkable except for elevated erythrocyte sedimentation rate $(E S R=94 \mathrm{~mm} / \mathrm{h})$ and positive antiproteinase-3 antibodies (by ELISA). The Mantoux test was negative. A maxillofacial CT performed before treatment showed an extensive thickening and sclerosis of the walls of the maxillary sinuses, sphenoid sinuses and ethmoidal air cells; nodular mucosal enhancement of the soft

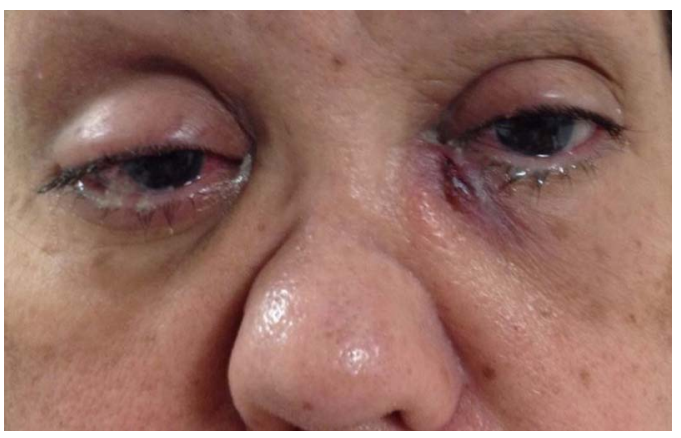

Figure 1 Saddle nose deformity and bilateral periorbital swelling, chemosis, dacryocystitis and scleritis.

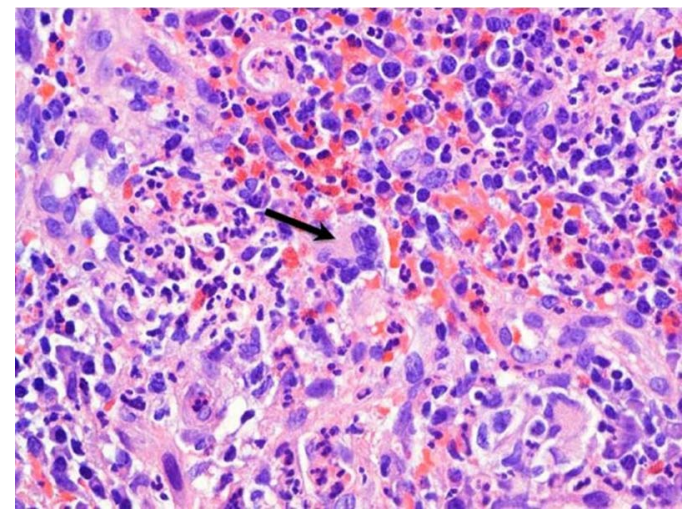

Figure 2 Area showing necrosis, abundant neutrophils, eosinophils and plasma cells. Multinucleated giant cells are also present (arrow; H\&E stain, $\times 400$ ).

tissue lining the maxillary sinuses and the nasal cavity; perforation of the nasal septum; and destruction of the uncinate process and destruction of the medial walls of the maxillary sinuses bilaterally. Nasal mucosa biopsy showed necrosis with a mixed inflammatory infiltrate and multinucleated giant cells consistent with GPA (figure 2). A chest CT scan showed bilateral cavitary nodules, left distal mainstem bronchus stenosis and a left apical bronchopleural fistula (figure 3). Bronchoscopy revealed a collapse of the left main bronchus. Bronchoalveolar lavage (BAL) fluid demonstrated a mixed inflammatory infiltrate and multinucleated giant cells. BAL fluid cultures were negative for bacteria, mycobacteria and fungi. Cytology was negative for malignant cells.

She was treated with intravenous methylprednisolone $2 \mathrm{mg} / \mathrm{kg}$ for 7 days followed by prednisone $1 \mathrm{mg} / \mathrm{kg} /$ day. The prednisone dose was decreased by $5 \mathrm{mg}$ every 2-4 weeks down to $25 \mathrm{mg}$. Also, she 
Figure 3 Chest CT (coronal, sagittal and axial views) before treatment. Bilateral cavitary nodules and left distal mainstem bronchus segmental stenosis (red arrow). Gas collection at the left apical pleuroparenchymal interface consistent with a bronchopleural fistula (yellow arrow).

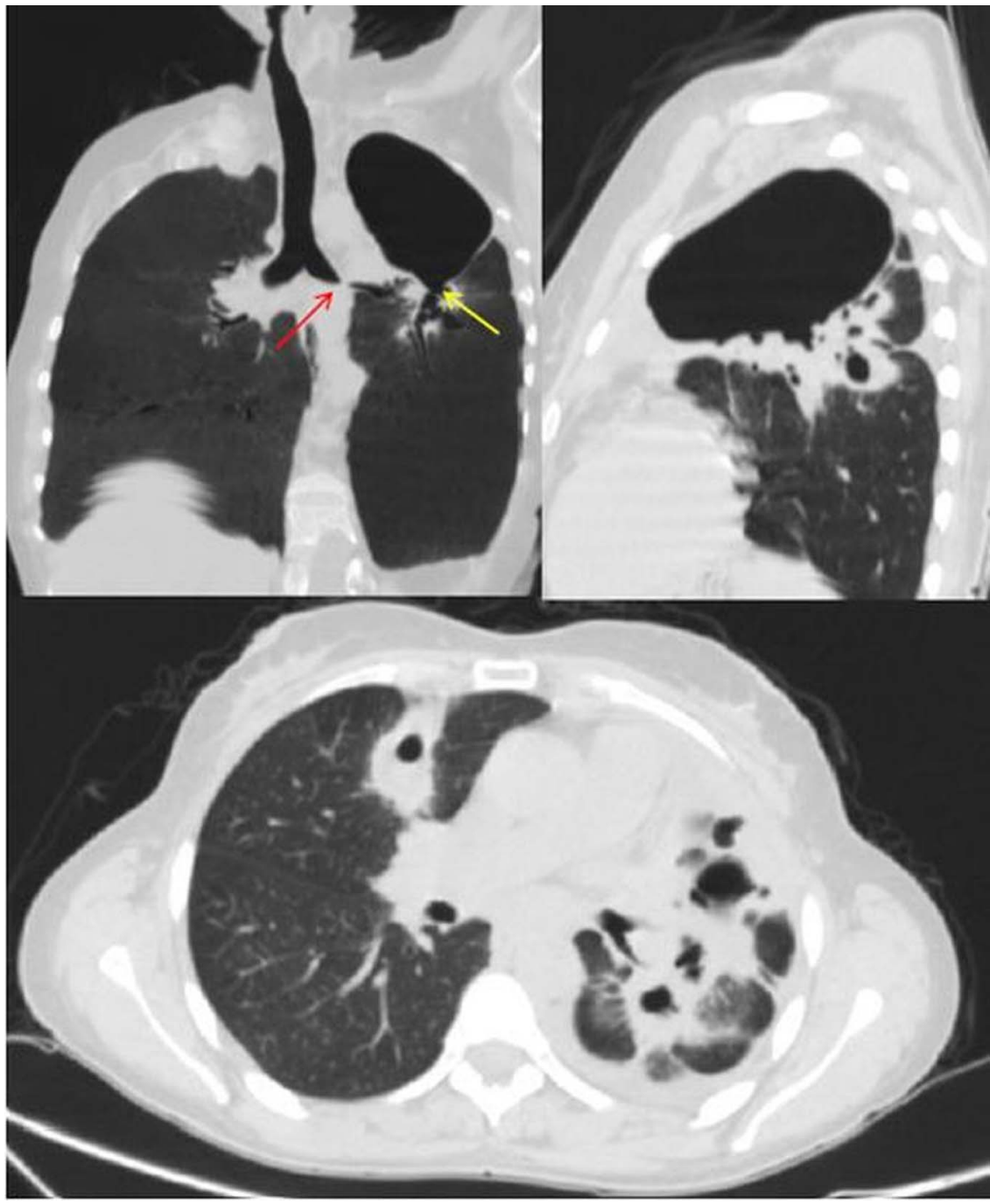

was treated with cyclophosphamide $2 \mathrm{mg} / \mathrm{kg}$ orally daily for 6 months followed by azathioprine $2 \mathrm{mg} / \mathrm{kg}$. During hospitalisation, she also received intravenous piperacillin/tazobactam for 10 days followed by prophylaxis with trimethoprim/sulfamethoxazole. Ocular, ear and sinus manifestations resolved after 1 month of treatment and ESR decreased to normal levels $(9 \mathrm{~mm} / \mathrm{h})$. Three months later, pulmonary function tests showed severe obstructive airway disease but normal diffusion capacity (diffusing capacity of the lungs for carbon monoxide $=91 \%$ of predicted value). Six months after treatment, the chest CT scan showed partial resolution of pulmonary nodules with residual scars, but persistent bronchopleural fistula and left bronchus stenosis (figure 4).

To the best of our knowledge, two other cases of bronchopleural fistula have been reported in GPA. ${ }^{2}{ }^{3}$ Immunosuppressive therapy resulted in the resolution of fistula in one case. Bronchopleural fistula appears to be a late manifestation in GPA. Thus, prompt diagnosis and treatment may prevent this complication.
Figure 4 Chest CT scan (sagittal and axial views) after treatment. Interval resolution of the cavitary bilateral pulmonary nodules with residual scars. Persistent left apical gas filled cavity at the pleuroparenchymal interface.

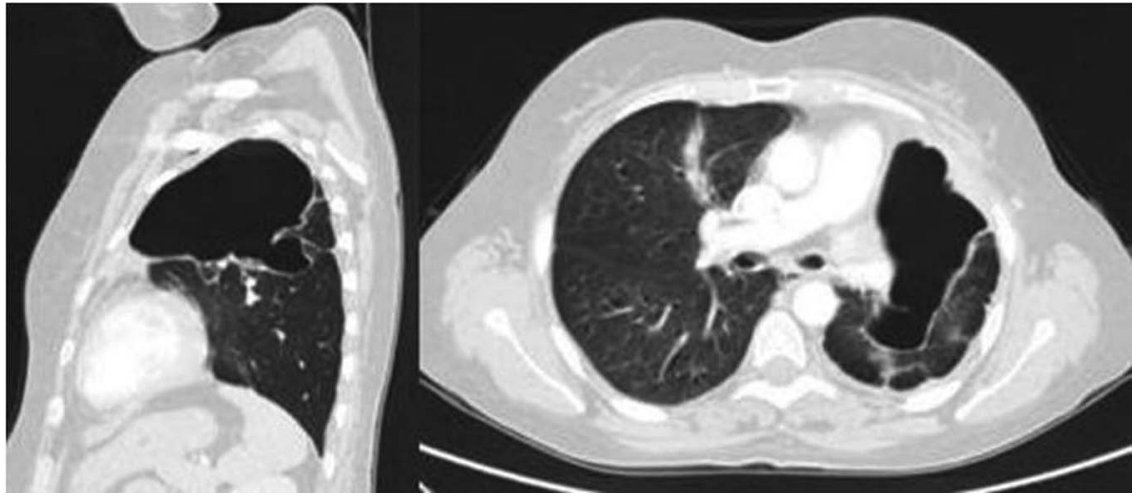




\section{Learning points}

- Granulomatosis with polyangiitis (GPA) may present with a wide range of pulmonary manifestations.

- Bronchopleural fistula is a rare manifestation of GPA.

- Prompt diagnosis and treatment of GPA may prevent this complication.

Contributors LMD-C, NdL-T, GR, LMV provided substantial contribution to acquisition of data; drafted the article or revised it critically; and approved the final version of the article to be published.
Competing interests None.

Patient consent Obtained.

Provenance and peer review Not commissioned; externally peer reviewed.

\section{REFERENCES}

1 Holle JU, Laudien M, Gross WL. Clinical manifestations and treatment of Wegener's granulomatosis. Rheum Dis Clin North Am 2010;36:507-26.

2 Koyama S, Murakami K, Sakakibara T, et al. Massive pleural effusion and bronchopleural fistula in Wegener's granulomatosis. Sarcoidosis Vasc Diffuse Lung Dis 2010;27:76-9.

3 Tao Y, Hayashi T, Nagatomo H, et al. [A case of limited Wegener's granulomatosis with hemophilia A, complicated by empyema, bronchopleural fistula and herpes zoster during therapy]. Nihon Kyobu Shikkan Gakkai Zasshi 1994;32:1073-7.

Copyright 2014 BMJ Publishing Group. All rights reserved. For permission to reuse any of this content visit http://group.bmj.com/group/rights-licensing/permissions.

BMJ Case Report Fellows may re-use this article for personal use and teaching without any further permission.

Become a Fellow of BMJ Case Reports today and you can:

- Submit as many cases as you like

- Enjoy fast sympathetic peer review and rapid publication of accepted articles

- Access all the published articles

- Re-use any of the published material for personal use and teaching without further permission

For information on Institutional Fellowships contact consortiasales@bmjgroup.com

Visit casereports.bmj.com for more articles like this and to become a Fellow 